\title{
Development and Validation of a Scale to Assess Social Entrepreneurship Competency in Higher Education
}

Carlos Capella-Peris, Jesús Gil-Gómez, Manuel Martí-Puig \& Paola RuízBernardo

To cite this article: Carlos Capella-Peris, Jesús Gil-Gómez, Manuel Martí-Puig \& Paola Ruíz-Bernardo (2019): Development and Validation of a Scale to Assess Social Entrepreneurship Competency in Higher Education, Journal of Social Entrepreneurship, DOI: 10.1080/19420676.2018.1545686

To link to this article: https://doi.org/10.1080/19420676.2018.1545686

曲 Published online: 20 Jan 2019.

Submit your article to this journal $₫$

Џ Article views: 13

View Crossmark data ¿ 


\title{
Development and Validation of a Scale to Assess Social Entrepreneurship Competency in Higher Education
}

\author{
Carlos Capella-Peris $^{\mathrm{a}, \mathrm{b}, \mathrm{c}}$ (D), Jesús Gil-Gómez ${ }^{\mathrm{a}}$ (D), Manuel Martí-Puig ${ }^{\mathrm{d}}$ and Paola \\ Ruíz-Bernardo ${ }^{\mathrm{d}}$ \\ a'Department of Education and Didactics of Specific Subjects, Universitat Jaume I, Castelló, Spain; \\ ${ }^{b}$ Department of Health, Physical Education, Recreation and Dance, Morgan State University, \\ Baltimore, MD, USA; ' Neuromuscular Symptoms Unit, Tissue Injury Branch, National Institute

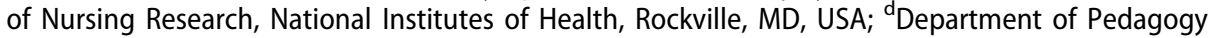 \\ and Didactics of Social Sciences, Language and Literature, Universitat Jaume I, Castelló, Spain
}

\begin{abstract}
This paper proposes an instrument to assess social entrepreneurship competency in higher education (SECS). 19 Features of social entrepreneurship competency were identified. The pilot test $(n=497)$ confirmed the validity and reliability of the SECS. Exploratory factor analysis proposed a set of categories consistent with the initial approach. Confirmatory factor analysis showed acceptable relationships among the scale categories and items, while the fit indices suggested that the data fit adequately to the default model. Pearson's test verified significant, positive correlations among the revised categories in all cases. Therefore, the scale carries the potential to contribute to social entrepreneurship research.
\end{abstract}

\section{KEYWORDS}

Social entrepreneurship competency; education assessment; scale validation; factor analysis

\section{Introduction}

Entrepreneurship promotion has previously been proposed within several communities in societies, primarily as a response to crisis situations. Indeed, it is often presented in the literature as the key to solve many of this world's persistent social problems (Olinsson 2017). Traditionally, researchers have analysed this concept from a purely economic point of view. However, it is necessary to focus on the potential social benefits of this phenomenon as well.

The main difference between for-profit/commercial and social entrepreneurship lies in the differing focus of each activity: the first aims to produce financial and economic profits, while the second focuses on creating social value (Auerswald 2009). Measuring and conceptualising how this improvement impacts on society has been recently discussed by Weaver (2018), in an effort to develop a unified perspective of the term social value. Social entrepreneurship embraces activities so as to discover, define and take advantage of opportunities to increase social wealth, develop new businesses or manage existing organisations in an innovative way (Zahra, Filatotchev, and Wright 
2009). It is also understood as a process of construction, evaluation and pursuit of opportunities for social change (Roberts and Woods 2005). On the other hand, social entrepreneurship is still subject to criticism related to such issues as political claims, democracy, citizenship, legitimacy or values attributed to markets and social welfare (Dart 2004; Eikenberry and Kluver 2004; Cho 2006; Nicholls 2010; Garrow and Hasenfeld 2014). However, the present study takes more positive perspective, highlighting the potential of social entrepreneurship in combating group disadvantage (Teasdale 2010).

Currently, no unified conception of social entrepreneurship has been accepted by scholars and practitioners (Roberts and Woods 2005; Weerawardena and Sullivan Mort 2006; Short, Moss, and Lumpkin 2009; Bacq and Janssen 2011; Choi and Majumdar 2014; Olinsson, 2017). For this reason, empirical research and analysis to examine the antecedents and consequences of social entrepreneurship has been slow in developing and setting up its own study field (Short et al. 2009). However, an emerging literature has examined how individuals become predisposed to create social enterprises (Mair and Noboa 2003), which has encouraged researchers to create scales to measure social entrepreneurship (Crucke and Decramer 2016; PerisOrtiz, Rueda-Armengot, and Palacios-Marqués 2016; Kannampuzha 2017). The approach taken in the current study differs from previous work in several key respects. First, it takes a detached, scholarly stance, aiming to ensure balance between social and entrepreneurial aspects rather than emphasising the entrepreneurial ones to the exclusion of others. Second, the study instrument and model include a wide range of personality features, enabling several kinds of social entrepreneurs to be identified in future applications of this instrument. Finally, the study is grounded in a deep review of both theoretical and practical literature, to ensure a strong foundation in both dimensions.

Several researchers emerging from different geographical and cultural communities of practice have followed diverse approaches to define social entrepreneurship, giving rise to different ways of understanding this phenomenon. Differing conceptions of capitalism and the role of governments give rise to profound differences in the ensuing studies. Three main schools of thought can be identified. The American Social Innovation School analyses the establishment of new and better means to tackle social problems or to satisfy social needs. Meanwhile, the American Social Enterprise School focuses on income generation through the social mission of entrepreneurship. Finally, the European Tradition has mainly been devoted to the concept of social enterprises (Bacq and Janssen 2011). Of these three perspectives, the first is the most relevant as it stresses the importance of the social entrepreneur as an individual, and on identifying his or her characteristic features; the present study is therefore based in this school of thought. Moreover, it is created a scale to assess the individual features of social entrepreneurs in Higher Education.

Previous research has identified a positive relationship between entrepreneurial personality features and entrepreneurial behaviour (Rauch and Frese 2007), suggesting the predictive validity of these personality characteristics (Collins, Hanges, and Locke 2004; Zhao and Seibert 2006). This relationship is not self-evident but predicts that the more personality features are shown, the more probable to be an entrepreneur. 
However, as with the definition of social entrepreneurship itself, there are no unified and accepted features related to entrepreneurial competency. Therefore, a scale to assess the social entrepreneurship in Higher Education is needed, not only to measure the promotion of this competency but also to define the personality features of social entrepreneurs.

\section{Literature review}

To create an effective tool to assess the promotion of social entrepreneurship in higher education, this project has analysed the specific features of this domain of competency. This literature review examines several applied and theoretical studies from different cultural and social contexts in depth. It is necessary to clarify at this point that, for this study, social entrepreneurship as a concept is interpreted as a compromise between 'social' and 'entrepreneurship' factors. Therefore, features at either extreme of the social and entrepreneurship framing, including empathy, morality, financial issues, marketing and so on, were not included. The most relevant databases in education were used to conduct the review, Scopus and Eric. Initially, all documents linked to the study of entrepreneurship and social entrepreneurship competencies were selected. Then, according to our theoretical foundation, those studies that were not embraced from a point of view of personality features were rejected. Thus, the 19 individual characteristics originally proposed were: leadership, goal-oriented motivation, confidence, organisation, responsibility, creativity, initiative, resilience, tolerance, social awareness, belonging to well-informed social networks, offering help and cooperation and values of commitment, coherence, coexistence and respect for public affairs, along with the abilities to identify opportunities, to take risks, to create ideas, to change and to learn and evolve (Robinson et al. 1991; Dees 1998; Alvord, Brown, and Letts 2004; De Pablo, Santos, and Bueno 2004; Weerawardena and Sullivan Mort 2006; Ali, Topping, and Tariq 2009; Lee and Lai 2010; Sánchez 2010; Othman, Hashim, and Ab Wahid 2012; Ram and Selvaraj 2012; Ghazali, Ibrahim, and Zainol 2013). Social entrepreneurship features can be exhibited in different ways and levels (Short et al. 2009; Choi and Majumdar 2014), so that several social entrepreneurship behaviours coexist at the same time. In fact, this behavioural complexity offers the main explanations as to why no unified and accepted conception of social entrepreneurship has yet emerged. However, "the closer a person gets to satisfying all these conditions, the more that person fits the model of a social entrepreneur" (Dees 1998, 4).

Due to the wide range of conceptualisations that have been applied to social entrepreneurship, previous studies have focused on different aspects without a consistent academic focus. For this reason, research focused on social entrepreneurship tends to diverge from economic or financial perspectives related to this concept, especially compared to large projects like the Global Entrepreneurship Monitor (Bosma and Harding 2007; Bygrave and Quill 2007). Then, certain studies have compared successful practices related to social entrepreneurship (Alvord et al. 2004), developed a framework to analyse economic and social entrepreneurship in parallel (Spear 2006) and proposed a bounded multidimensional model of the phenomenon (Weerawardena and Sullivan Mort 2006). Even though social entrepreneurship research has matured, 
there are still many gaps in our knowledge about this filed (Lubberink et al. 2018), so more research is needed.

In addition, survey literature about research in social entrepreneurship has identified several issues: the number of empirical studies about the topic is limited, most studies have relied on qualitative research methods, quantitative research to date has consisted mainly in exploratory studies, very few research projects have used scales, rigorous hypothesis testing is lacking and most of this research is based on relatively small sample sizes (Short et al. 2009; Hoogendoorn, Pennings, and Thurik 2010). Taking these observations into account, some authors believe that the greatest challenge for social entrepreneurship research is the collection and measurement of data (Short et al. 2009). Academic progress in research about social entrepreneurship will thus not advance significantly until more quantitative studies have been performed (Cummings 2007). Certainly, a wider variety of research methods and models of social entrepreneurship would increase the reliability and validity of the studies while maximising the available insight from the data (Van de Ven and Johnson 2006). Hence, the instrument developed and validated in this article will make a positive contribution to social entrepreneurship research.

Finally, there are several areas of interest in entrepreneurship and social entrepreneurship research that are specific to higher education. For example, exploring such topics as entrepreneurial attributes among students in a public university (Ali, Topping, and Tariq 2010), the entrepreneurial potential of prospective child care providers in a public university or college of technology (Lee and Lai 2010), the experiences of pre-service teachers in educational programmes aiming to develop awareness about the relationship between entrepreneurship and social responsibility (Maistry and Ramdhani 2010), the promotion of attitudes conducive to social entrepreneurship among university students (Espíritu 2011), awareness of the social entrepreneurship among higher education students as a stepping stone to create more graduate social entrepreneurs (Kirby and Ibrahim 2011), the readiness of students and the internal environment of public universities in the implementation of entrepreneurship education (Othman et al. 2012), the impact of online entrepreneurship education proceeding from public and private institutions of higher education (Ram and Selvaraj 2012), and the factors that influence students' perceptions of entrepreneurial behaviour (Ghazali et al. 2013). This situation points out a growing research interest in social entrepreneurship in higher education; the instrument created for this study has the potential to be highly relevant in this context. Besides, advancing in research about social entrepreneurship will also provide additional indirect benefits to the community, related to its social mission.

Moreover, different educational programmes try to develop the social entrepreneurship features identified previously, suggesting a fertile environment to cultivate this competency within the community. Similarly, students enrolled in higher education are the most relevant population for these proposals, because of their likely opportunities to fulfil new and innovative projects in the near future. All these facts highlight the importance of promoting social entrepreneurship competency through higher education. The specific tool developed and validated in the next sections will be crucial to properly assess such relevant competency. 


\section{Main goal}

Due to the growing interest in social entrepreneurship and the potential benefits its promotion may bring to the community from higher education institutions, the specific objective of this research project is to develop and validate a specific instrument to assess social entrepreneurship competency in higher education.

\section{Method}

Following the approaches of previous studies (Piazza and Siebert 2008; Lemos et al. 2011; Coetzee 2014; Daniels et al. 2014; Cumming et al. 2015), several steps were taken: literature review (previously showed), initial scale proposal, expert judgement (logical review), pilot test (empirical review), exploratory factor analysis (EFA) and confirmatory factor analysis (CFA). All statistical tests and the EFA were conducted using the SPSS software (version 24.0). To perform the CFA AMOS software (version 24.0) was used.

\section{Initial scale proposal}

As explained in the literature review, 19 features of the social entrepreneurship competency were identified, based on the studies analysed. After these characteristic features had been defined, the scale items that had been used to measure them were then reviewed. Based on this procedure, the following research instruments were highlighted: the entrepreneurial inclinations of prospective teachers' (Ali et al. 2009), the entrepreneurial attitude orientation (Robinson et al. 1991), the attitudes and social cognitive strategies (Moraleda, Gonzalez, and Garcia-Gallo 2004) and the attitudes towards social responsibility (Alonso 2004). These various prior tests provided measures for each of the 19 theoretically defined social entrepreneurship features, ensuring the nomological validity of our proposal: the scale related to other, prior constructs in accordance with a relevant and broader theory (Cronbach and Meehl 1955). As previously mentioned, this proposal is based in the American Social Innovation School, which stresses the individual features of social entrepreneurs. In line with this theoretical approach, the items for the survey instrument were written in ' $I$ ' statements. Meanwhile, if another school of thought had been followed, other aspects of social entrepreneurship would be measured, including characteristics of, direct recipients, small communities or wider society.

The selected items were then grouped into three categories, labelled as personal, social and innovative features. According to the literature review, and specifically the assumptions of the school of thought followed, these three represented the main areas of interest in the analysis of the personality characteristics of social entrepreneurs. From this material, an initial scale proposal was created to carry out the validation process. This first version of the Social Entrepreneurship Competency Scale (SECS) had 96 items. 


\section{Results}

\section{Expert judgement}

A logical review of the initial scale was undertaken to assess the validity of the construct based on expert judgement. To do this, six experts in the topics of social entrepreneurship and higher education (three each) rated all items in terms of four aspects: quality, relevance, comprehensibility and association with the features under study. The first three aspects were rated from 1 (great) to 3 (poor), while the last aspect assigned each item to one of the 19 features theoretically proposed for measurement. The social entrepreneurship experts worked for international non-profit organisations or had successfully founded a national non-profit. The higher education members represented Business, Education and Social Work schools from three public Spanish universities.

Kendall's Coefficient of Concordance $(W)$ was used to assess the level of agreement of the experts' opinions. This coefficient shows the correlation among the judges' assessments for each aspect consulted (significance level $p<.05$ ). The results obtained in this test for quality, relevance, comprehensibility and feature association aspects are $W=.233, d f=95, p=.006 ; W=.313, d f=95, p=.000 ; W=.219, d f=95, p=.023 ; W$ $=.702, d f=95, p=.000$, respectively. These results demonstrate a significant level of positive agreements among the judges, in all cases. The levels of concordance are weak $(.2 \leq W<.4)$ for the quality, relevance and comprehensibility analysis, and strong $(.6 \leq W<.8)$ for the feature association analysis.

Then a critical review of the initial items was performed to select the most appropriate elements. Every item was required to meet three main criteria to be selected: for each of the first three aspects assessed, the mean must be less than or equal to 1.5 while the coefficient of variation is less than or equal to $37 \%$, for the feature association, the mode must be equal or exceed $50 \%$. The first of these requirements ensured that the items selected had high scores and homogeneous distribution in quality, relevance and comprehensibility. The final requirement ensured that each item had been located in the same dimension by at least three of the six judges. As a result of this critical review, the SECS was reduced from 96 to 30 items in the second version. Despite the significant reduction in the number of items, only two characteristic features of the social entrepreneurship competency were discarded from the theoretical proposal. These two elements, organisation and tolerance, were therefore rejected because none of the items used to measure them in previous studies met the three screening criteria applied.

A pilot test of the SECS was then developed to allow both EFA and CFA. The second version of the scale was therefore administered to a large sample of higher education students $(n=497)$. For each item, a five-point Likert-type scale, from 1 (strongly disagree) to 5 (strongly agree), was included to rate the responses of the students. The university students selected had all previously enrolled in educational programmes to promote their social entrepreneurship competency, namely courses offered within the Education and Social Work Schools of a Spanish public university. 


\section{Pilot test}

Once the student responses were recorded, the descriptive statistics for all items were extracted (Table 1 near here). The lowest mean obtained in this pilot test was 2.63 (item 2), while the highest was 4.61 (item 16). These data showed that the participants had enhanced their social entrepreneurship competency as expected.

The distribution of the global sample was then analysed by extracting a histogram from the collected data. These data have a normal distribution, with a high total mean of $3.83 \pm .314$ for the population as a whole.

The reliability analysis of all items shows a high .820 result on Cronbach's Alpha (Cronbach 1951), demonstrating a strong level of reliability for the SECS. The sensitivity of the dataset to outliers was also examined, looking to see whether the total Cronbach's Alpha changed noticeably in case any of the items was deleted. The results of this procedure showed no significant variations from the total value, obtaining a .809 in the lowest case (deleting item 27) and a .829 in the highest (deleting item 23). These results show that all items are important to assess social entrepreneurship competency.

Before continuing with the validation process of the SECS, two tests were employed to verify whether the items were related strongly enough to conduct the factor analysis: the Kaiser-Meyer-Olkin (KMO) Measure of Sampling Adequacy and the Bartlett's test of Sphericity (Comrey 1978). The closer to 1 the KMO value is, the more similar are the variances of the items; a high value of .816 was recorded in the KMO test,

Table 1. Descriptive statistics from the pilot test.

\begin{tabular}{|c|c|c|c|c|c|c|c|c|c|c|c|}
\hline Item & $N$ & Min & Max & Range & Sum & Mean & Mean std. E. & Std. deviation & Variance & Skewness & Kurtosis \\
\hline ¡1 & 497 & 1 & 5 & 4 & 1694 & 3.41 & 0.041 & 0.918 & 0.843 & -0.568 & -0.044 \\
\hline i2 & 497 & 1 & 5 & 4 & 1308 & 2.63 & 0.044 & 0.971 & 0.943 & 0.302 & -0.267 \\
\hline ¡3 & 497 & 1 & 5 & 4 & 2123 & 4.27 & 0.029 & 0.645 & 0.416 & -0.687 & 1.321 \\
\hline i4 & 497 & 2 & 5 & 3 & 2097 & 4.22 & 0.029 & 0.649 & 0.422 & -0.472 & 0.283 \\
\hline i5 & 497 & 2 & 5 & 3 & 2067 & 4.16 & 0.035 & 0.773 & 0.598 & -0.729 & 0.258 \\
\hline i6 & 497 & 1 & 5 & 4 & 1790 & 3.6 & 0.033 & 0.728 & 0.53 & -0.294 & 0.386 \\
\hline ¡7 & 497 & 2 & 5 & 3 & 1817 & 3.66 & 0.032 & 0.724 & 0.525 & -0.044 & -0.289 \\
\hline i8 & 497 & 2 & 5 & 3 & 1976 & 3.98 & 0.031 & 0.681 & 0.463 & -0.433 & 0.471 \\
\hline ¡9 & 497 & 2 & 5 & 3 & 1983 & 3.99 & 0.03 & 0.67 & 0.449 & -0.391 & 0.421 \\
\hline ¡10 & 497 & 1 & 5 & 4 & 2122 & 4.27 & 0.028 & 0.615 & 0.379 & -0.605 & 1.57 \\
\hline i11 & 497 & 1 & 5 & 4 & 2034 & 4.09 & 0.033 & 0.729 & 0.532 & -0.802 & 1.394 \\
\hline i12 & 497 & 1 & 5 & 4 & 1941 & 3.91 & 0.042 & 0.927 & 0.86 & -0.71 & 0.233 \\
\hline i13 & 497 & 1 & 5 & 4 & 1644 & 3.31 & 0.039 & 0.861 & 0.742 & -0.277 & 0.041 \\
\hline ¡14 & 497 & 1 & 5 & 4 & 1811 & 3.64 & 0.039 & 0.866 & 0.75 & -0.159 & -0.191 \\
\hline i15 & 497 & 1 & 5 & 4 & 2142 & 4.31 & 0.027 & 0.61 & 0.372 & -0.609 & 1.441 \\
\hline ¡16 & 497 & 1 & 5 & 4 & 2293 & 4.61 & 0.025 & 0.561 & 0.314 & -1.388 & 2.953 \\
\hline ¡17 & 497 & 1 & 5 & 4 & 2165 & 4.36 & 0.025 & 0.564 & 0.318 & -0.43 & 1.393 \\
\hline i18 & 497 & 1 & 5 & 4 & 2270 & 4.57 & 0.027 & 0.609 & 0.371 & -1.362 & 2.41 \\
\hline i19 & 497 & 1 & 5 & 4 & 1831 & 3.68 & 0.049 & 1.097 & 1.204 & -0.086 & 0.084 \\
\hline i20 & 497 & 1 & 5 & 4 & 1759 & 3.54 & 0.031 & 0.695 & 0.483 & -0.286 & 0.468 \\
\hline i21 & 497 & 1 & 5 & 4 & 1835 & 3.69 & 0.028 & 0.628 & 0.395 & -0.29 & 0.427 \\
\hline i22 & 497 & 1 & 5 & 4 & 1512 & 3.04 & 0.049 & 1.098 & 1.206 & -0.194 & -0.809 \\
\hline ¡23 & 497 & 1 & 5 & 4 & 1479 & 2.98 & 0.054 & 1.198 & 1.435 & 0.011 & -0.827 \\
\hline i24 & 497 & 1 & 5 & 4 & 1972 & 3.97 & 0.027 & 0.602 & 0.362 & -0.769 & 2.97 \\
\hline i25 & 497 & 1 & 5 & 4 & 1936 & 3.9 & 0.033 & 0.747 & 0.558 & -0.382 & 0.151 \\
\hline ¡26 & 497 & 1 & 5 & 4 & 1763 & 3.55 & 0.034 & 0.761 & 0.579 & -0.16 & -0.024 \\
\hline i27 & 497 & 1 & 5 & 4 & 1722 & 3.46 & 0.034 & 0.751 & 0.564 & -0.109 & 0.113 \\
\hline ¡28 & 497 & 1 & 5 & 4 & 1865 & 3.75 & 0.043 & 0.964 & 0.929 & -0.533 & -0.228 \\
\hline$i 29$ & 497 & 2 & 5 & 3 & 2061 & 4.15 & 0.028 & 0.632 & 0.4 & -0.368 & 0.431 \\
\hline$i 30$ & 497 & 1 & 5 & 4 & 2075 & 4.18 & 0.029 & 0.647 & 0.419 & -0.588 & 1.302 \\
\hline
\end{tabular}


which is a satisfactory result. The Bartlett test outcomes also indicated a significant common ground among the items (significance level $p<.05$ ), because it obtained a $\chi^{2}(435)=3698.715, p=.000$ result. Based on these findings, it was determined that the collected data from the SECS met all the requirements to proceed with the factor analysis.

\section{Exploratory factor analysis}

An EFA was used to determine the internal structure of the SECS, establishing in which categories the items ought to be grouped. The EFA was conducted using the extraction method of principal component analysis. The rotation method used in this test was Varimax with Kaiser Normalization. The rotation converged in eight interactions, showing the three main categories that explain $32.6 \%$ of the cumulative variance.

Regarding the extraction of common factors, the items are distributed in three main groups (Table 2). This distribution is consistent with the initial, theoretically based approach about personal, social and innovative features.

To examine the location of each item, a component plot in a rotated space graphic was extracted from the collected data, establishing the specific location of each item after the rotation performed through the EFA; this figure (not included in the publication) showed that all items were very close to one another.

Table 2. Rotated component matrix from the EFA.

\begin{tabular}{|c|c|c|c|}
\hline \multirow[b]{2}{*}{ Item } & \multicolumn{3}{|c|}{ Component } \\
\hline & 1 & 2 & 3 \\
\hline i8 & .736 & -.040 & .074 \\
\hline i9 & .728 & -.006 & .119 \\
\hline i7 & .668 & -.067 & .281 \\
\hline ¡3 & .647 & .144 & -.016 \\
\hline i4 & .521 & .250 & .022 \\
\hline ¡28 & .435 & .207 & .169 \\
\hline i6 & .422 & .178 & .184 \\
\hline i5 & .284 & .231 & .049 \\
\hline i19 & .255 & .225 & .131 \\
\hline ¡15 & .011 & .680 & .185 \\
\hline ¡16 & -.076 & .654 & .013 \\
\hline ¡18 & .180 & .651 & -.054 \\
\hline i30 & .333 & .488 & .054 \\
\hline i10 & .308 & .454 & -.186 \\
\hline i17 & .384 & .451 & -.010 \\
\hline ¡25 & .187 & .436 & .136 \\
\hline ¡14 & -.104 & .435 & .197 \\
\hline ¡29 & .393 & .428 & -.085 \\
\hline ¡11 & .288 & .385 & -.064 \\
\hline i24 & .157 & .375 & .229 \\
\hline ¡1 & .061 & .118 & .592 \\
\hline i22 & -.069 & -.070 & .563 \\
\hline $\mathrm{i} 27$ & .427 & .096 & .531 \\
\hline ¡26 & .406 & .117 & .486 \\
\hline $\mathrm{i} 20$ & .174 & .196 & .473 \\
\hline i13 & .063 & .108 & .460 \\
\hline i21 & .351 & .162 & .408 \\
\hline i2 & .202 & -.019 & .403 \\
\hline $\mathrm{i} 23$ & -.002 & -.069 & .321 \\
\hline i12 & -.093 & .274 & .299 \\
\hline
\end{tabular}


Despite obtaining the same number of categories in this new distribution as in the initial organisation (three), the structure of the categories after EFA differed somewhat from the original formulation. However, this new distribution of items and the related social entrepreneurship features is more balanced, so the SECS was reorganised according to the results of EFA result, giving rise to the revised categories of personal, social and innovative features, respectively (Tables 3-5).

Even after this reorganisation, 10 of the 17 features of social entrepreneurship competency remained in their originally associated categories. Confidence, goal-

Table 3. Revised category of personal features from the EFA.

\begin{tabular}{lll}
\hline Code & \multicolumn{1}{c}{ Item } & \multicolumn{1}{c}{ Associated feature } \\
\hline i8 & I believe in my potential & Confidence \\
i9 & I consider myself self-sufficient in achieving my goals & Goal-oriented motivation \\
i7 & I believe I am capable of dealing with most situations & Confidence \\
i3 & I am determined to achieve my goals & Goal-oriented motivation \\
i4 & I think it is necessary to take risks to make progress & Ability to take risks \\
i28 & I always look for the positive side in bad situations & Ability to learn and evolve \\
i6 & I like to take calculated risks with new ideas & Ability to take risks \\
i5 & I think people who take risks are more likely to succeed than those who do not & Ability to take risks \\
i19 & I am able to do things imaginatively, in a different way from how others do them & Creativity \\
\hline
\end{tabular}

Table 4. Revised category of social features from the EFA.

\begin{tabular}{|c|c|c|}
\hline Code & Item & Associated feature \\
\hline i15 & I like helping my friends and classmates & $\begin{array}{l}\text { Offering help and } \\
\text { cooperation }\end{array}$ \\
\hline i16 & People who help others are an example to follow & Social awareness \\
\hline ¡18 & Coexistence problems can be solved by dialogue & $\begin{array}{l}\text { Coexistence and respect } \\
\text { for public affairs }\end{array}$ \\
\hline i30 & I believe that opportunities can be extracted from problems or difficult situations & Resilience \\
\hline i10 & I take on the consequences of what I have said or done & Responsibility \\
\hline ¡17 & I usually perform very well in my role of any business project I am involved in & Commitment and coherence \\
\hline $\mathrm{i} 25$ & I enjoy finding effective solutions for problems that nobody has looked at yet & Ability to create ideas \\
\hline ¡14 & I would rather collaborate for free in a non-governmental organisation & Social awareness \\
\hline ¡29 & I analyse my mistakes to learn from them & Ability to learn and evolve \\
\hline i11 & I do every job as thoroughly as possible & Responsibility \\
\hline i24 & I am able to formulate suggestions to improve projects in which I participate & Ability to create ideas \\
\hline
\end{tabular}

Table 5. Revised category of innovative features from the EFA.

\begin{tabular}{|c|c|c|}
\hline Code & Item & Associated feature \\
\hline i1 & I like coordinating other people while working in collaboration & Leadership \\
\hline $\mathrm{i} 22$ & $\begin{array}{l}\text { Sometimes I have participated in the implementation of group } \\
\text { projects or collaborations }\end{array}$ & Initiative \\
\hline ¡27 & I am good at handling unforeseen situations & Ability to change \\
\hline i26 & I improvise without difficulty when plans change & Ability to change \\
\hline $\mathrm{i} 20$ & I envision new uses for common objects & Creativity \\
\hline i13 & I have access to the information required to become an entrepreneur & $\begin{array}{l}\text { Belonging to well-informed } \\
\text { social networks }\end{array}$ \\
\hline i21 & I am able to create business opportunities and to take advantage of them & Ability to identify opportunities \\
\hline i2 & When working in groups I prefer to be the leader & Leadership \\
\hline $\mathrm{i} 23$ & $\begin{array}{l}\text { I have seriously considered starting my own business sometime } \\
\text { after finishing my degree }\end{array}$ & Initiative \\
\hline ¡12 & I prefer to work in situations that involve more people & $\begin{array}{l}\text { Belonging to well-informed } \\
\text { social networks }\end{array}$ \\
\hline
\end{tabular}


oriented motivation and the ability to take risks are retained as personal features. The revised category of social features includes all features originally proposed, such as offering help and cooperation, social awareness, commitment and coherence and coexistence and respect for public affairs. Lastly, initiative and the abilities to change and to identify opportunities continued to be identified as innovative features. The minor changes required in the new distribution of categories, in fact, supported the underlying structure of the initial proposal.

On the other hand, 5 of the 17 features changed their associated category: leadership and belonging to well-informed social networks change from personal to innovative features; responsibility moves from personal to social features; and both resilience and the ability to create ideas switch from innovative to social features. All of these changes were accepted, because these features suited to the revised categories. Despite these changes, the items related to 15 elements of the social entrepreneurship competency remain assigned together to the same category.

However, in two cases the items related to the same feature were located in different categories. For creativity, one item was moved to the revised category of personal features while the other remained in the innovative features group. In the second case, the ability to learn and evolve, one item is now located in the revised category of personal features while the other remained among the social features. These changes were accepted in both cases because creativity and the ability to learn and evolve can be analysed as both as personal and innovative characteristics, or as personal and social features, respectively.

To finalise the EFA, a reliability test was performed for the revised categories. The reliability of these factors was good $(\alpha \geq .70)$ for the personal and social feature groups, and acceptable $(\alpha \geq .60)$ in the innovative features category, taking into account the level of analysis and the reduced numbers of items included in each case.

\section{Confirmatory factor analysis}

To assess the distribution proposed in the EFA, a CFA was conducted, verifying whether the data fit to a hypothesised measurement model (default model). The goal of this procedure was thus to demonstrate the consistency of the new distribution proposed. Globally, the path diagram (Figure 1 near here) shows acceptable relationships among the factors (categories) and items.

To test the default model, the following indices were analysed: the Root Mean Square Residual (RMR <.08), Root Mean Square Error of Approximation (RMSEA < .06), Goodness of Fit Index (GFI > .90) and Adjusted Goodness of Fit Index (AGFI > .90) were used as absolute fit indices, while the relative chi-square $\left(\chi^{2} / d f<4\right)$ and Comparative Fit Index (CFI > .90) were employed as relative fit indices (Hoyle 1995; Kline 2005). The main results in these tests are (Table 6 near here).

The RMR and RMSEA tests showed good outcomes, while the GFI and AGFI results are close to the reference levels. Similarly, the relative fit indices reflected an excellent outcome on the relative chi-square test and a value close to the reference level in the CFI. Despite the GFI, AGFI and CFI were under .90, Greenspoon and Saklofske (1998) stablish a value of .80 for acceptable results. In addition, it is necessary to highlight 


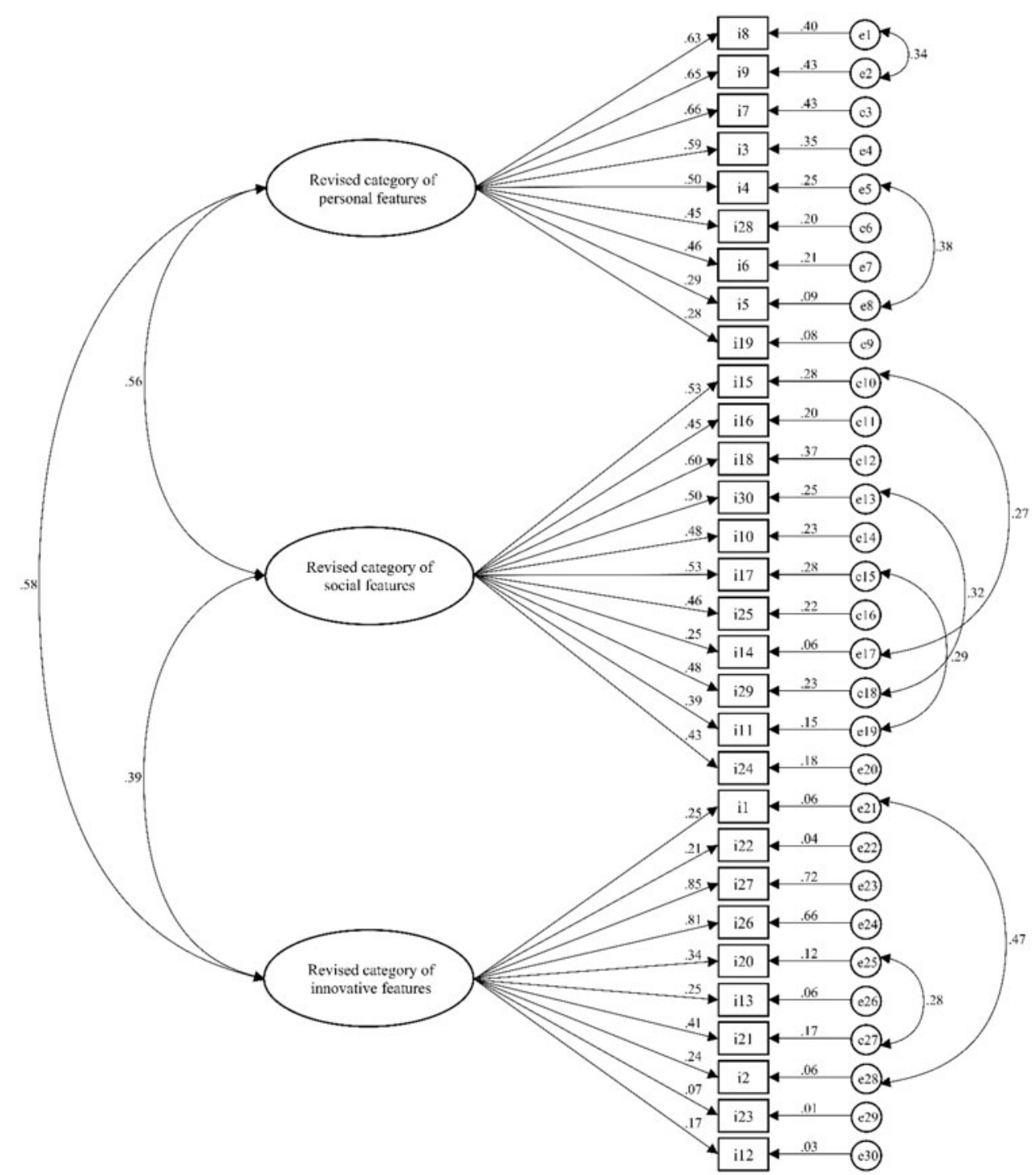

Figure 1. Path diagram from the CFA.

Table 6. Absolute and relative fit index results from the CFA.

\begin{tabular}{lccccc}
\hline RMR & RMSEA & GFI & AGFI & $\chi^{2} / \mathrm{df}$ & CFI \\
\hline .042 & .059 & .872 & .849 & 2.707 & .798 \\
\hline
\end{tabular}

that several tests were applied to analyse the scale, but it is no required to satisfy all of them to accept the proposal. Thus, overall, the data offered an adequate fit to the default model of distribution.

Finally, a correlation test was performed to evaluate the linear correlation among the three new factors, using the Pearson coefficient (Pearson 1948). The results obtained are $r_{p}=.473, p=.000$ for the correlation between the revised personal and 
social categories, $r_{\mathrm{p}}=.417, p=.000$ for the revised personal and innovative categories and $r_{\mathrm{p}}=.304, p=.000$ for the revised social and innovative categories. These results showed significant, positive correlations within the new categories in all cases (significance level $p<.05)$. The correlation levels in these comparisons are moderate $\left(.4 \leq r_{\mathrm{p}}\right.$ $<.6)$ in the first two cases and low $\left(.2 \leq r_{\mathrm{p}}<.4\right)$ in the last one.

After this development and validation processes, the items included on the scale were re-numbered to present the final version of the SECS (Table 7).

Finally, to test the reliability of the SECS in a different context, the Cronbach's Alpha test was performed once again with a medium-sized sample of higher education students $(n=150)$. These students had been enrolled at a public university in the United States, in educational programmes related to Business and Management,

Table 7. The SECS.

\begin{tabular}{|c|c|c|c|c|c|c|}
\hline & & $\begin{array}{l}\text { Strongly } \\
\text { disagree }\end{array}$ & Disagree & Midpoint & Agree & $\begin{array}{l}\text { Strongly } \\
\text { agree }\end{array}$ \\
\hline 1 & I believe in my potential. & 1 & 2 & 3 & 4 & 5 \\
\hline 2 & I consider myself self-sufficient in achieving my goals. & 1 & 2 & 3 & 4 & 5 \\
\hline 3 & I believe I am capable of dealing with most situations. & 1 & 2 & 3 & 4 & 5 \\
\hline 4 & I am determined to achieve my goals. & 1 & 2 & 3 & 4 & 5 \\
\hline 5 & I think it is necessary to take risks to make progress. & 1 & 2 & 3 & 4 & 5 \\
\hline 6 & I always look for the positive side in bad situations. & 1 & 2 & 3 & 4 & 5 \\
\hline 7 & I like to take calculated risks with new ideas. & 1 & 2 & 3 & 4 & 5 \\
\hline 8 & $\begin{array}{l}\text { I think people who take risks are more likely to succeed } \\
\text { than those who do not. }\end{array}$ & 1 & 2 & 3 & 4 & 5 \\
\hline 9 & $\begin{array}{l}\text { I am able to do things imaginatively, in a different way } \\
\text { from how others do them. }\end{array}$ & 1 & 2 & 3 & 4 & 5 \\
\hline 10 & I like helping my friends and classmates. & 1 & 2 & 3 & 4 & 5 \\
\hline 11 & People who help others are an example to follow. & 1 & 2 & 3 & 4 & 5 \\
\hline 12 & Coexistence problems can be solved by dialogue. & 1 & 2 & 3 & 4 & 5 \\
\hline 13 & $\begin{array}{l}\text { I believe that opportunities can be extracted from prob- } \\
\text { lems or difficult situations. }\end{array}$ & 1 & 2 & 3 & 4 & 5 \\
\hline 14 & $\begin{array}{l}\text { I take on the consequences of what I have said } \\
\text { or done. }\end{array}$ & 1 & 2 & 3 & 4 & 5 \\
\hline 15 & $\begin{array}{l}\text { I usually perform very well in my role of any business } \\
\text { project I am involved in. }\end{array}$ & 1 & 2 & 3 & 4 & 5 \\
\hline 16 & $\begin{array}{l}\text { I enjoy finding effective solutions for problems that } \\
\text { nobody has looked at yet. }\end{array}$ & 1 & 2 & 3 & 4 & 5 \\
\hline 17 & $\begin{array}{l}\text { I would rather collaborate for free in a non-governmen- } \\
\text { tal organisation. }\end{array}$ & 1 & 2 & 3 & 4 & 5 \\
\hline 18 & I analyse my mistakes to learn from them. & 1 & 2 & 3 & 4 & 5 \\
\hline 19 & I do every job as thoroughly as possible. & 1 & 2 & 3 & 4 & 5 \\
\hline 20 & $\begin{array}{l}\text { I am able to formulate suggestions to improve projects } \\
\text { in which I participate. }\end{array}$ & 1 & 2 & 3 & 4 & 5 \\
\hline 21 & $\begin{array}{l}\text { I like coordinating other people while working in } \\
\text { collaboration. }\end{array}$ & 1 & 2 & 3 & 4 & 5 \\
\hline 22 & $\begin{array}{l}\text { Sometimes I have participated in the implementation of } \\
\text { group projects or collaborations. }\end{array}$ & 1 & 2 & 3 & 4 & 5 \\
\hline 23 & I am good at handling unforeseen situations. & 1 & 2 & 3 & 4 & 5 \\
\hline 24 & I improvise without difficulty when plans change. & 1 & 2 & 3 & 4 & 5 \\
\hline 25 & I envision new uses for common objects. & 1 & 2 & 3 & 4 & 5 \\
\hline 26 & $\begin{array}{l}\text { I have access to the information required to become an } \\
\text { entrepreneur. }\end{array}$ & 1 & 2 & 3 & 4 & 5 \\
\hline 27 & $\begin{array}{l}\text { I am able to create business opportunities and to take } \\
\text { advantage of them. }\end{array}$ & 1 & 2 & 3 & 4 & 5 \\
\hline 28 & When working in groups I prefer to be the leader. & 1 & 2 & 3 & 4 & 5 \\
\hline 29 & $\begin{array}{l}\text { I have seriously considered starting my own business } \\
\text { sometime after finishing my degree. }\end{array}$ & 1 & 2 & 3 & 4 & 5 \\
\hline 30 & I prefer to work in situations that involve more people. & 1 & 2 & 3 & 4 & 5 \\
\hline
\end{tabular}


Education and Urban Studies, or Social Work Schools. Similar results were recorded: .887 in all items and .752; .705 and .762 in the personal, social and innovative features categories, respectively; these findings verified the reliability of the SECS.

\section{Discussion and conclusions}

After the literature review, the analysis of the social entrepreneurship competency was undertaken according to the main school of thought about this topic (Bacq and Janssen 2011). The scale subsequently developed therefore has strong theoretical support, with the SECS including specific features identified by Robinson et al. (1991), Dees (1998), Alvord et al. (2004), De Pablo et al. (2004), Weerawardena and Sullivan Mort (2006), Ali et al. (2009), Lee and Lai (2010), Sánchez (2010), Othman et al. (2012), Ram and Selvaraj (2012) and Ghazali et al. (2013). In addition, the processes of development and validation of the scale follow that performed for similar works (Piazza and Siebert 2008; Lemos et al. 2011; Coetzee 2014; Daniels et al. 2014; Cumming et al. 2015). Altogether, this strengthens the value of the SECS, ensuring a wide range of possible application for the instrument.

A rigorous critical review by experts ensured the high quality, relevance and comprehensibility of the SECS items, as well as appropriate association of items with features. Likewise, despite the strict criteria applied, only 2 of the 19 original social entrepreneurship features were removed from the first proposal. Once again, this situation highlights the strong theoretical support for the scale and the appropriate selection of features to measure the social entrepreneurship competency.

Statistically, the excellent results obtained in the pilot test reinforce its theoretical foundation. In addition, the SECS yielded a strong reliability value for all items on Cronbach's Alpha test, without significant variation if any of the items was deleted. In addition, the Kaiser-Meyer-Olkin and the Bartlett tests show a high score and a significant result, respectively, verifying that the items are related strongly enough to conduct the factor analysis.

The EFA performed a first assessment of the SECS structure, determining that the items should be distributed in three main groups as expected. Although this new distribution is similar and consistent with the initial (theoretically based) approach, certain items were reassigned in comparison to the original proposal. However, the revised distribution is more balanced and easier to understand than the first version, thereby improving the structure of the SECS.

Using the CFA, a second and deeper study of the SECS structure was conducted. The results showed acceptable relationships among the categories and items in the new model. Moreover, after evaluating the absolute and relative fit indices, highlighted by the great results of RMR, RMSEA and $\chi^{2} / d f$ tests, it was concluded that the degree of fit to the default model of distribution is significantly strong. Finally, the Pearson's correlation test established significant, positive correlations among the revised categories in all cases, once again supporting the structure of the SECS.

In conclusion, the initial goal of the project was met, as a complete process was performed to develop and validate a useful scale to assess the social entrepreneurship competency in higher education programmes. Indeed, considering the outstanding 
results obtained, and the strong theoretical and statistical support for this tool, the SECS was found to be a new and promising tool for measuring this competency in different educational programmes and social contexts.

Furthermore, this scale meets several key requirements for social entrepreneurship research, such as setting up its own field of study, deepening in empirical research analysis and facilitating data collection and measurement (Short et al. 2009). Altogether, these results draw attention to the high potential value of the SECS. On the other hand, the main limitation of this research is that it is mainly focused on the educational field. However, the strong theoretical foundation suggests a wider range of application. Indeed, future research should apply the validated instrument, not only to test the promotion of social entrepreneurship competency in Higher Education and other fields but also to test the scale in practice.

\section{ORCID}

Carlos Capella-Peris (D) http://orcid.org/0000-0003-2520-0650

Jesús Gil-Gómez (D) http://orcid.org/0000-0003-4737-4766

Paola Ruíz-Bernardo (D) http://orcid.org/0000-0003-1939-4401

\section{References}

Ali, A., K. J. Topping, and R. H. Tariq. 2009. "Entrepreneurial Inclinations of Prospective Teachers." New Horizons in Education 57 (2): 1-16. http://files.eric.ed.gov/fulltext/EJ860820.pdf.

Ali, A., K. J. Topping, and R. H. Tariq. 2010. "Entrepreneurial Attributes among Postgraduate Students of a Pakistani University." US-China Education Review 7 (5): 66-77. http://www.davidpublishing.com/show.html?6044.

Alonso, F. J. 2004. "Adquisicion de actitudes de responsabilidad social a traves de un programa de voluntariado [Acquisition of social responsibility attitudes through a volunteer program]." PhD diss., Universitat de Valencia. http://www.tdx.cat/bitstream/handle/10803/10301/alonso. pdf? sequence $=1$.

Alvord, S. H., L. D. Brown, and C. W. Letts. 2004. "Social Entrepreneurship and Societal Transformation: An Exploratory Study." The Journal of Applied Behavioral Science 40 (3): 260-282. doi:10.1177/0021886304266847.

Auerswald, P. 2009. "Creating Social Value." Stanford Social Innovation Review 7 (2): 51-55. http://www.forwardci.org/images/stories/TWPReadingCreatingSocialValue.pdf

Bacq, S., and F. Janssen. 2011. "The Multiple Faces of Social Entrepreneurship: A Review of Definitional Issues Based on Geographical and Thematic Criteria." Entrepreneurship \& Regional Development: An International Journal 23 (5/6): 373-403. doi:10.1080/08985626.2011.577242.

Bosma, N., and R. Harding. 2007. Global Entrepreneurship Monitor. GEM 2006 Results. London: Babson and London Business School. http://www.babson.edu/Academics/centers/blank-center/globalresearch/gem/Documents/gem-2006-global-report.pdf.

Bygrave, W. D., and M. Quill. 2007. Global entrepreneurship monitor. 2006 financing report. London: Babson and London Business School. http://www.babson.edu/Academics/centers/ blank-center/globalresearch/gem/Documents/gem-2006-financing-report.pdf.

Cho, A. H. 2006. "Politics, Values and Social Entrepreneurship: A Critical Appraisal." In Social Entrepreneurship, edited by J. Mair, J. Robinson, and K. Hockerts, 34-56. New York: Palgrave.

Choi, N., and S. Majumdar. 2014. "Social Entrepreneurship as an Essentially Contested Concept: Opening a New Avenue for Systematic Future Research." Journal of Business Venturing 29 (3): 363-376. doi:10.1016/j.jbusvent.2013.05.001. 
Coetzee, M. 2014. "Measuring Student Graduateness: Reliability and Construct Validity of the Graduate Skills and Attributes Scale." Higher Education Research \& Development 33 (5): 887-902. doi:10.1080/07294360.2014.890572.

Collins, C. J., P. J. Hanges, and E. A. Locke. 2004. "The Relationship of Achievement Motivation to Entrepreneurial Behavior: A Meta-Analysis." Human Performance 17 (1): 95-117. doi:10.1207/ S15327043HUP1701_5.

Comrey, A. L. 1978. "Common Methodological Problems in Factor Analytical Studies." Journal of Consulting and Clinical Psychology 46 (4): 648-659. doi:10.1037/0022-006X.46.4.648.

Cronbach, L. J. 1951. "Coefficient Alpha and the Internal Structure of Tests." Psychometrika 16 (3): 297-334. doi:doi:10.1007/BF02310555.

Cronbach, L. J., and P. E. Meehl. 1955. "Construct Validity in Psychological Tests." Psychological Bulletin 52 (4): 281-302. doi:10.1037/h0040957.

Crucke, S., and A. Decramer. 2016. "The Development of a Measurement Instrument for the Organizational Performance of Social Enterprises." Sustainability 8 (2): 161. doi:10.3390/ su8020161.

Cumming, J., C. Woodcock, S. J. Cooley, M. J. G. Holland, and V. E. Burns. 2015. “Development and Validation of the Groupwork Skills Questionnaire (GSQ) for Higher Education." Assessment \& Evaluation in Higher Education 40 (7): 988-1001. doi:doi:10.1080/02602938.2014.957642.

Cummings, T. G. 2007. "Quest for an Engaged Academy." Academy of Management Review 32 (2): 355-360. doi:10.5465/AMR.2007.24349184.

Daniels, L. M., C. Poth, C. Papile, and M. Hutchison. 2014. "Validating the Conceptions of Assessment-III Scale in Canadian Preservice Teachers." Educational Assessment 19 (2): 139-158. doi:10.1080/10627197.2014.903654.

Dart, R. 2004. "The Legitimacy of Social Enterprise." Nonprofit Management and Leadership 14 (4): 411-424. doi:10.1002/nml.43.

De Pablo, I., B. Santos, and Y. Bueno. 2004. "Las dimensiones del perfil del emprendedor: Contraste empirico con emprendedores de exito [The dimensions of the entrepreneur profile: empirical contrast with successful entrepreneurs]." In El emprendedor innovador y la creacion de empresas de I+D+l [the innovative entrepreneur and the I+D+l enterprises creation], edited by S. Roig, D. Ribeiro, V. R. Torcal, A. De la Torre, and E. Cerver, 813-830. Valencia: Universitat de Valencia. http://www.uv.es/motiva/libromotiva/51PabloSantosBueno.pdf.

Dees, J. G. 1998. The meaning of social entrepreneurship. Kansas city, MO and Palo Alto, CA: Kauffman Foundation and Stanford University. http://sehub.stanford.edu/sites/default/files/ TheMeaningofsocialEntrepreneurship.pdf

Eikenberry, A. M., and J. D. Kluver. 2004. "The Marketization of the Nonprofit Sector: Civil Society at Risk?" Public Administration Review 64 (2): 132-140. doi:10.1111/j.1540-6210.2004.00355.x.

Espíritu, R. 2011. "Actitud emprendedora en los estudiantes universitarios: un analisis de factores explicativos en la Comunidad de Madrid [Entrepreneurial attitude in universitystudents: an analysis of explanatory factors in the Community of Madrid]." PhD diss., Universidad Complutense de Madrid. http://eprints.ucm.es/12803/1/T32967.pdf.

Garrow, E. E., and Y. Hasenfeld. 2014. "Social Enterprises as an Embodiment of a Neoliberal Welfare Logic." American Behavioral Scientist 58 (11): 1475-1493. doi:10.1177/0002764214534674.

Ghazali, Z., N. A. Ibrahim, and F. A. Zainol. 2013. "Factors Affecting Entrepreneurial Intention among UniSZA Students." Asian Social Science 9 (1): 85-93. doi:10.5539/ass.v9n1p85.

Greenspoon, P. J., and D. H. Saklofske. 1998. "Confirmatory Factor Analysis of the Multidimensional Student's Life Satisfaction Scale." Personality and Individual Differences 25 (5): 965-971. doi:10.1016/S0191-8869(98)00115-9.

Hoogendoorn, B., E. Pennings, and R. Thurik. 2010. What do We Know About Social Entrepreneurship: An Analysis of Empirical Research. Rotterdam: Erasmus Research Institute of Management (ERIM) and Erasmus University. http://hdl.handle.net/1765/16558.

Hoyle, R. H. 1995. Structural Equation Modeling: Concepts, Issues, and Applications. London: Sage.

Kannampuzha, M. J. 2017. "Understanding and Measuring Social Entrepreneurship." PhD diss., Jyväskylä University). https://jyx.jyu.fi/dspace/bitstream/handle/123456789/53242/978-951-396992-9_v\%C3\%A4it\%C3\%B6s24032017.pdf?sequence=1 
Kirby, D. A., and N. Ibrahim. 2011. "The Case for (social) Entrepreneurship Education in Egyptian Universities." Education + Training 53 (5): 403-415. doi:10.1108/00400911111147712.

Kline, R. 2005. Principles and Practice of Structural Equation Modeling. 3rd ed. New York, NY: The Guildford Press.

Lee, L. S., and C. C. Lai. 2010. "An Exploratory Survey of Prospective Childcare Givers' Entrepreneurial Potential in Taiwan." Paper presented at the International Conference on Business and Information (BAI2010), Kitakyushu, Japan, July 5-7. http://files.eric.ed.gov/fulltext/ED510783.pdf.

Lemos, M. S., C. Queiros, P. M. Teixeira, and I. Menezes. 2011. "Development and Validation of a Theoretically Based, Multidimensional Questionnaire of Student Evaluation of University Teaching." Assessment \& Evaluation in Higher Education 36 (7): 843-864. doi:10.1080/ 02602938.2010.493969.

Lubberink, R., V. Blok, J. van Ophem, G. van der Velde, and O. Omta. 2018. "Innovation for Society: Towards a Typology of Developing Innovations by Social Entrepreneurs." Journal of Social Entrepreneurship 9 (1): 52-78. doi:10.1080/19420676.2017.1410212.

Mair, J., and E. Noboa. 2003. Social Entrepreneurship: How Intentions to Create a Social Enterprise Get Formed. IESE Working Paper No. D/521. doi:10.2139/ssrn.462283.

Maistry, S. M., and J. Ramdhani. 2010. "Integrating Social Responsibility into an Entrepreneurship Education Program: A Case Study." US-China Education Review 7 (4): 23-29. http://www.davidpublishing.com/show.html?6030.

Moraleda, M., A. Gonzalez, and J. Garcia-Gallo. 2004. AECS: Actitudes y estrategias cognitivas sociales [SCAS: Social cognitive attitudes and strategies]. 2nd ed. Madrid: TEA Ediciones.

Nicholls, A. 2010. "The Legitimacy of Social Entrepreneurship: Reflexive Isomorphism in a Pre-Paradigmatic Field." Entrepreneurship." Entrepreneurship Theory and Practice 34 (4): 611-633. doi:10.1111/j.1540-6520.2010.00397.x.

Olinsson, S. B. 2017. "Social Entrepreneurship-Committing Theory to Practice." Journal of Social Entrepreneurship 8 (2): 225-247. doi:10.1080/19420676.2017.1375547.

Othman, N., N. Hashim, and H. Ab Wahid. 2012. "Readiness towards Entrepreneurship Education: Students and Malaysian Universities." Education + Training 54 (8/9): 697-708. doi:10.1108/ 00400911211274837.

Pearson, K. 1948. Early Statistical Papers. Cambridge: University Press.

Peris-Ortiz, M., C. Rueda-Armengot, and D. Palacios-Marqués. 2016. "Is It Possible to Measure Social Entrepreneurship in Firms?" Cuadernos de Gestión 16 (2): 15-28. doi:10.5295/cdg.140469mp.

Piazza, C. L., and C. F. Siebert. 2008. "Development and Validation of a Writing Dispositions Scale for Elementary and Middle School Students." The Journal of Educational Research 101 (5): 275-286. doi:10.3200/JOER.101.5.275-286.

Ram, B. S., and M. Selvaraj. 2012. "Impact of Computer Based Online Entrepreneurship Distance Education in India." Turkish Online Journal of Distance Education. IETC 13 (3): 247-259. http:// tojde.anadolu.edu.tr/makale_goster.php?id=798.

Rauch, A., and M. Frese. 2007. "Let's Put the Person Back into Entrepreneurship Research: A Meta-Analysis on the Relationship between Business Owners' Personality Traits, Business Creation, and Success." European Journal of Work and Organizational Psychology 16 (4): 352-385. doi:10.1080/13594320701595438.

Roberts, D., and C. Woods. 2005. "Changing the World on a Shoestring: The Concept of Social Entrepreneurship." University of Auckland Business Review 7 (1): 45-51. http://www.thebookshelf.auckland.ac.nz/docs/UABusReview/2005_07_i01-05-asd.pdf.

Robinson, P. B., D. V. Stimpson, J. C. Huefner, and H. K. Hunt. 1991. "An Attitude Approach to the Prediction of Entrepreneurship." Entrepreneurship Theory and Practice 15 (4): 13-31.

Sánchez, J. C. 2010. "Evaluacion de la Personalidad Emprendedora: Validez Factorial Del Cuestionario de Orientacion Emprendedora (COE) [Entrepreneurial Personality Assessment: Factorial Validity of the Entrepreneurial Orientation Questionnaire (EOQ)]." Revista Latinoamericana de Psicologia 42 (1): 41-52. doi:10.14349/rlp.v42i1.397. 
Short, J. C., T. W. Moss, and G. T. Lumpkin. 2009. "Research in Social Entrepreneurship: Past Contributions and Future Opportunities." Strategic Entrepreneurship Journal 3 (2): 161-194. doi:10.1002/sej.

Spear, R. 2006. "Social Entrepreneurship: A Different Model?" International Journal of Social Economics 33 (5/6): 399-410. doi:10.1108/03068290610660670.

Teasdale, S. 2010. "How Can Social Enterprise Address Disadvantage? Evidence from an Inner City Community." Journal of Nonprofit \& Public Sector Marketing 22 (2): 89-107. doi:10.1080/ 10495141003601278.

Van De Ven, A. H., and P. E. Johnson. 2006. "Knowledge for Theory and Practice." Academy of Management Review 31 (4): 802-821. doi:10.5465/AMR.2006.22527385.

Weaver, R. L. 2018. "Re-Conceptualizing Social Value: Applying the Capability Approach in Social Enterprise Research." Journal of Social Entrepreneurship 9 (2): 79-93. doi:10.1080/ 19420676.2018 .1430607$.

Weerawardena, J., and G. Sullivan Mort. 2006. "Investigating Social Entrepreneurship: A Multidimensional Model." Journal of World Business 41 (1): 21-35. doi:10.1016/j.jwb.2005.09.001.

Zahra, S. A., I. Filatotchev, and M. Wright. 2009. "How Do Threshold Firms Sustain Corporate Entrepreneurship? The Role of Boards and Absorptive Capacity." Journal of Business Venturing 24 (3): 248-260. doi:10.1016/j.jbusvent.2008.09.001.

Zhao, H., and S. E. Seibert. 2006. "The Big Five Personality Dimensions and Entrepreneurial Status: A Meta-Analytical Review." Journal of Applied Psychology 91 (2): 259-271. doi:10.1037/ 0021-9010.91.2.259. 